\title{
ETHNIC RELATIONS AND ETHNOCENTRISM IN SELECTED MALAYSIAN SHORT STORIES
}

\author{
${ }^{1 *}$ Ahmad Zufrie Abd Rahman and ${ }^{2}$ Ida Baizura Bahar \\ ${ }^{1,2}$ Department of English, Faculty of Modern Languages and Communication \\ Universiti Putra Malaysia, 43400 Serdang, Malaysia \\ *Corresponding author: gs49403@student.upm.edu.my
}

\begin{abstract}
The issues of the ethnic diversity of the Malaysian way of life, have been explored in scholarship on Fernando's selection of Malaysian Short Stories (2006), consisting of six fictional narratives on life in preindependence Malaya namely "Nannan and A Certain Cry" by Cynthia Anthony, "Ratnamuni" by K.S. Maniam, "Pasang" by Pretam Kaur, "The Third Child" by K.S. Maniam, and "Birthday" by M. Shanmugalingam, through the lens of post-colonialism. The stories have been described as an exceptional compilation due to the fact that Fernando is able to assemble stories written by authors from different ethnic backgrounds and cultures other than their own but we argue in this paper that the short stories do not contain intercultural sensitivity as they depict more ethnocentric orientations. We define ethnocentric experiences here as interculturally-sensitive elements which trigger a series of complex emotions in avoiding cultural differences either by denying their existence, raising defences against them, or by minimising their importance. Using the understanding of ethnocentrism as conceptualised by Milton J. Bennet (2013) as part of his Developmental Model of Intercultural Sensitivity, we attempt to examine the type of ethnocentric experiences depicted by the authors through selected characters in two out of the six short stories. Our findings demonstrate that the three types of ethnocentric experiences, denial, defense and minimisation of cultural differences, are indeed found embedded in the unconscious minds of the authors through their portrayals of selected characters, which in turn provide a platform of cultural fertilisation in Malaysian pluralistic society.
\end{abstract}

Key words: Malaysian short stories, ethnocentrism, denial, defense, minimisation

\section{Introduction}

Since Malaya gained her independence in 1957 and the formation of Malaysia in 1963, Malaysia has always been a pluralistic society with 31 million population comprises of various ethnic groups namely Malays and other bumiputra (son of the soil), Chinese, Indian, and others which make up 68.8 per cent, 23.2 per cent, 7 per cent, and 1.0 per 
cent of the composition respectively (Malaysian Department of Statistics, 2017: 2). With this in mind, the term 'ethnic' or 'ethnicity' in the Malaysian society and politics writings are often used interchangeably with the term 'race', resulting from a confused understanding of both terms (Mustapha, 2014: 11). Etymologically, the word 'ethnic', derived from the Greek word 'ethnos,' was originated from the word 'ethnikos' that denotatively means heathen or pagan (Mustapha, 2014: 8).

In present-day Malaysian usage, however, the terms 'ethnicity' or 'ethnic' are associated with a classification of people and group relationships based on Mustapha's (2014) premise that "an ethnic group arises from two crucial factors, namely interaction which is based on shared ethnic traits". For that reason, the ideas of ethnic and ethnicities as groups who interact with each other based on shared ethnic traits has had become the basis of the 1Malaysia Negaraku concept. It is a concept earlier introduced as 1Malaysia in 2009, which has been one of the strategies under the Malaysian National Unity policy, to become a guiding principle to build a united and progressive nation in the $21^{\text {st }}$ century by cultivating integration between races through ties reinforcement and cooperation between races, especially when faced with challenges (Wan Hussin, 2010, p. 233). As a result, Malaysians are now generally enjoying a prosperous and harmonious life than before, and Malaysia is often recognised as an example of a multi-racial developing country and often has been referred to by other developing countries as prime example of a successful nation of multiethnic unity (Muis, et. al 2012: 1).

Unfortunately, it has been argued that this success does not give any significant impact to ethnic relations in Malaysia as statistical and observation evidences from other studies show otherwise. Taking Zahara Aziz, Amla Salleh and Jainabee Kassim's (2007) study, for instance, they verified that relationships between ethnics in Malaysia has waned because of community members' attitudes that are too concerned with ethnicity. This fact is then further proven by Comber (2011) and Yong (2013) which indicate that every ethnic group preferred to socialise only with their own ethnicity. This shows that the relationship between ethnics in Malaysia is still at the average level as the level of tension index between communities significantly showed an upward trend from 2011 to 2013 (Ridzuan, 2016: 4). Furthermore, the mainstream Malaysian newspaper, The New Straits Times, on March 22 ${ }^{\text {nd }}, 2017$, also reported that Malaysia racial discrimination based on ethnicity in education, healthcare, finance, workforce and welfare continued an upward trend in spite of continuing efforts implemented by the government.

To make matters worse, unsurprisingly, the lack of ethnic relations in pluralistic Malayan society before independence had also spilt over into Malaysian literary scene especially among Malaysian authors in English because ethnic representations have been made essential instead of race consciousness (Raihanah, 2009: 4). Although Zawiah (2004) earlier highlighted this issue; that the literary outputs were just imitations of the English literature to which the Malaysian authors in English were exposed during their school years, our study, however, argues that the lack of ethnic relations depicted by the characters in Malaysian Literature in English (MLIE) show 
that the narratives also lack intercultural sensitivity, an area which has been neglected by Malaysian authors in English that gives a significant impact on ethnocentrism. This is due to the fact that people with a higher degree of intercultural sensitivity were less ethnocentric than people with a lower degree of intercultural sensitivity (Chen, 2010: 6).

With these debates framing the research background of our study, this paper attempts to examine the type of ethnocentric experiences depicted by the authors through selected characters in two selected short stories, "A Certain Cry" (2006) and "Nannan" (2006) by Cynthia Anthony (n.d.). This, in turn, will be able to provide a platform of cultural fertilisation in Malaysian pluralistic ethnicities, using the understanding of ethnocentrism as conceptualised by Milton J. Bennet (2013) as part of his Developmental Model of Intercultural Sensitivity.

\section{Literature Review}

Literature written in English by Malaysian writers is a relatively recent event that only began in the 1949, although Tanah Melayu (the Malay Peninsula) had been under British colonial rule since the nineteenth century (Quayum, 2001). During the early stage of its development, Quayum (2008) described the production of works written in English by Malaysian authors as sporadic attempts and its development was later stunted by the institutionalisation of Bahasa Malaysia as the national language, a misconception of the society, and the lack of tradition and race consciousness in the works by the Anglophone writers as compared to Malay literature. The Malaysian government has been described as providing an 'uncompromising notion of what constitutes its national literariness' (Quayum, 2001) where only works written in the Malay language are acknowledged and, hence, nominated for awards and for national laureate status.

Literature written in English, on the other hand, is categorised as sectional literature together with other creative writings of other languages spoken in the country. Nevertheless, the hardship and suffering faced, culturally and politically, are indeed blessings in disguise, whereby Quayum (2008) asserted that 'it has also benefited from the relative freedom potentiality and adaptability of the language and its contemporary cosmopolitanism'. More to the point, Raihanah (2009) also believed that, after half a decade of independence, through the intersections and interactions of personal, ethnic-cultural and national needs, Malaysian authors in English would have established those needs to meet the challenges of multiculturalism. However, in contrast to these views by Quayum (2008) and Raihanah (2009), we believe that the 'freedom' and 'intersections and interactions of personal, ethnic-cultural and national' needs, as depicted by the Malaysian authors in English, are yet to be examined critically focusing on intercultural communication sensitivity in order to meet the challenges of multiculturalism. As Raihanah (2009: 57) argued, some of Malaysian authors in English are more ethnocentric in their work using their community of origin as the persona of their fictions. 
In particular, a selection of Malaysian Short Stories (2006) by Lloyd Fernando, consisting of six fictional narratives on life in pre-independence Malaya, namely "Nannan and A Certain Cry" by Cynthia Anthony, "Ratnamuni" by K.S. Maniam, "Pasang" by Pretam Kaur, "The Third Child" by K.S. Maniam, and "Birthday" by M. Shanmugalingam, has been used as the compulsory reading texts for the Malaysian Higher School Certificate or Sijil Tinggi Pelajaran Malaysia (STPM), 920 Literature in English 2012 syllabus, an examination which is equivalent to A-level in the United Kingdom. In STPM, 920 Literature in English is offered as one of the elective subjects to be taken by STPM candidates. The syllabus comprises of three assessment structures namely Term 1, Term 2 and Term 3 in which each term is divided into three literary genres namely poetry and short stories (Paper 1), plays (Paper 2) and novels (Paper 3) respectively. Through the study of canonical texts and non-canonical texts spanning out the three terms, the syllabus aims to enable candidates to engage with and make informed responses of the texts studied, to enhance candidates' aesthetic sense and moral awareness, and to develop candidates' critical and creative thinking as well as the following soft skills; communication, questioning, persuading, problemsolving, and organising, interpersonal and multicultural sensitivity, research, ICT, and life-long learning, and time management (Malaysian Examinations Council, 2011: 1-7).

Firstly, in Maniam's first published short story, "Ratnamuni" (1981), Wicks (2002) delineated that the dramatic monologue, as a form of characterization, has made the form, language and content of the narrative dynamic enough to convey the intrinsic values of Hinduism to the readers. Maniam has breached more profoundly into the soul of Indian immigrants than any other writers of his time (Fernando, 1981: 75). In addition, Maniam also showed his precision in capturing the nuances of uneventful lives in a small town Malaysian Indian family (Fernando, 1981: 76) in The Third Child. Interestingly, a familiar point of contention about Maniam's writings is that both narratives are representations of ethnocentricism in nature because both narratives are much centred on the migrant experience, especially that of the Indian community in Malaysia (as cited in Fadhillah, 2013).

Unlike Maniam's writings, Cynthia's writings in "Nannan" and "A Certain Cry" display her powerful combination of realism with emotions (Fernando, 1981: 74) in which the former revolves on the countless suffering of a Burmese-Portuguese woman for the sake of her family (Quayum, 2008: 14) while the latter revolves on the barbaricmerciless act of catching and killing frogs for cooking (Fernando, 1981: 74). Here we encounter another similar point of argument to that of Maniam's about Cynthia's writings in which both narratives are exhibitions of ethnocentric experiences of the characters as we argue that both narratives focus more on the Burmese-Portuguese suffering experience and solitary socialisation of rural-folks respectively. Pretam's "Pasang", on the other hand, illustrates her fine ability to use allegory to represent the idea of poverty (Quayum, 2008: 158) and her fine evocation of Punjabi Malaysian life (Fernando, 1981: 76). Lastly, in "Birthday" by M. Shanmugalingam, Fernando (1981) reported that the British novelist, Iris Murdoch, was very impresssed after reading the narrative on Indian family lives which qualified the short story to win a prize in a short story competition organised by Isis, the Oxford University student magazine. 
Proceedings of the $1^{\text {st }}$ Annual International Conference on Language and Literature, 18-19 April 2018, Fakultas Sastra, UISU, Medan, Indonesia

\section{Research Method}

Our study employed a literary textual analysis involving close readings of two short stories selected in which examples are extracted from the short stories and serve as evidence in our analysis. The close textual analysis was used to determine the ways in which the relationships between the characters' experiences and the developmental mental positions of ethnocentrism define the type of ethnocentric experience. Meanwhile, a close reading, analysing carefully what the characters say and describe, is necessary in order to examine their ethnocentric developmental mental position as proposed by Bennet (2013). Although the model proposes six different kinds of experience spread across the continuum; from ethnocentrism to ethnorelativism, for the purpose of our study, only three kinds of ethnocentrism experiences were used in our analysis, namely denial, defense and minimisation of cultural differences as illustrated in Figure 1 below.

Figure 1: Stages of Ethnocentrism (Bennet, 2013)

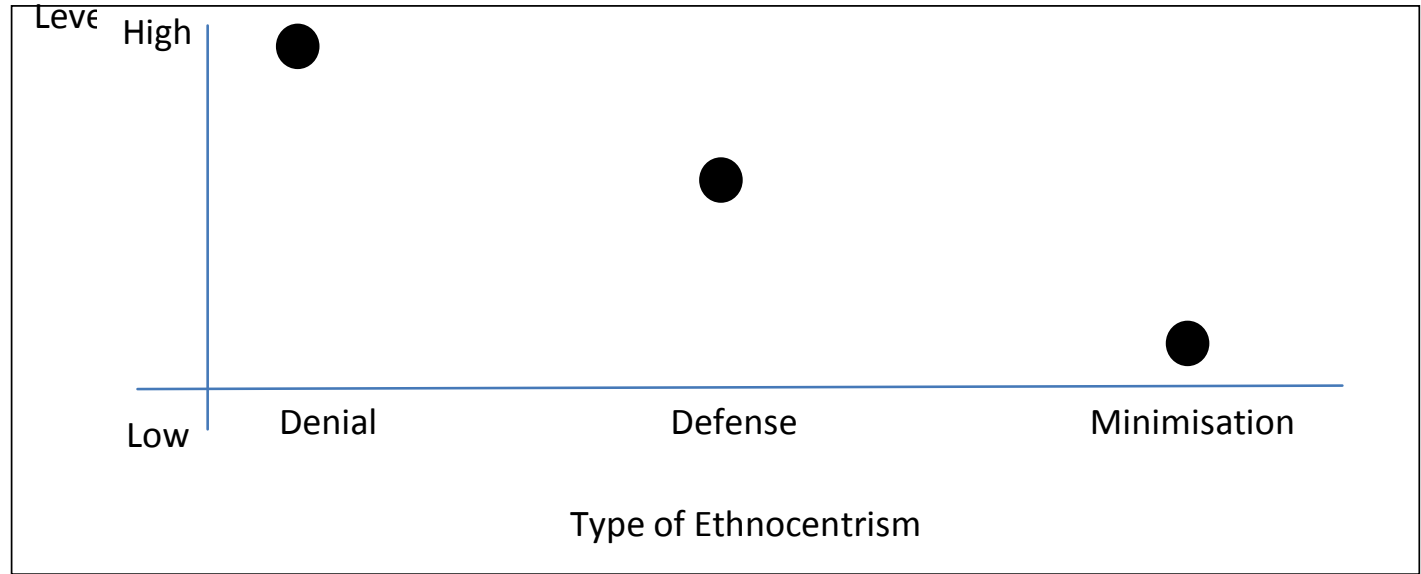

As illustrated in Figure 1, denial of cultural differences is the highest ethnocentric experience, followed by defense against cultural differences and minimisation of cultural differences as the lowest ethnocentric experience. According to Bennet (2013), denial of cultural difference is a state in which one upholds his or her own culture in term of its patterns or beliefs, behaviours and values experienced as the only one which is actual and true. In spite of that, no visible cultural differences can be seen or, if it has, only in imprecise ways. In general, a person with a denial perspective shows his or her disinterests towards cultural differences and towards national culture differences even though the differences are brought to his or her attention. Consequently, the main issue to be resolved at this highest stage of ethnocentric experience is the tendency to avoid perceiving or defying cultural difference and, once it resolves, the next stage of ethnocentric cultural difference appears, namely defense against cultural differences.

Bennet (2013) explained that, at the defense stage, one experiences one's own or an adapted culture as the only feasible, civilised and the best way to live, even though exposure to cultural differences are more real than that of a person who is in a state of denial. Bennet (2013) also added that what appears to be 'real' cultural differences 
experienced by a person with a defense perspective are regarded as stereotypical; therefore, a person, at this stage, is "more openly threatened by cultural differences than people who are in a state of denial because the world is organised into "us and them', where one's own culture is superior and other cultures are inferior". At this stage, Bennet (2013) also highlighted that a person of dominant culture is likely to experience defense as an assault to his or her value which are often apparent to others as privilege, while a person of the non-dominant culture is more likely to experience defense as 'discovering and solidifying a separate cultural identity' in contrast to the dominant person, causing positive stereotyping of one's own culture and negative stereotyping of other cultures.

In contrast to denial, defense has its own variation which is known as reversal; defined as when an adopted culture is experienced as superior to the culture of one 's primary socialisation (Bennet, 2013). He added that unlike defense, reversal only maintains the polarisation of 'us and them' worldview as seen in defense because it does not maintain the notion of other cultures as threats and negative stereotyping is usually associated with the incorporation of others' negative stereotyping in one's conscious or subconscious mind. To resolve the issues involving defense, Bennet (2013) suggested communality establishment as the solution instead of introducing more complicated understanding of differences and, when it is achieved, the stage is set to move into the minimisation of cultural differences

As the lowest level of ethnocentrism, Bennet (2013) defined minimisation of cultural differences as universalities of one's own cultural worldview experienced in which the associated threat to cultural differences experienced in the former stage is soothed by considering the differences into familiar categories namely physical transcendent universalisms. With regards to physical universalism, cultural differences could possibly be treated with the exceptional similarities of people's biological nature in which the similarities experienced may then be generalised to other assumed natural phenomena, such as needs and motivations, with the assumptions that typologies could be applied equally well in all cultures. In terms of transcendent universalism, cultural differences could possibly be treated with assumed 'cross-cultural applicability of certain religious, economic, political, or physical concepts'. Bennet (2013), however, noted that, having a religion is not regarded as ethnocentric, unless one assumes that a person from other culture either does or would share his or her belief.

Unlike denial and defense, minimisation celebrates similarities which lead to the issue of insistency about correcting one's behaviour to match another person from other culture's expectation. At this stage, Bennet (2013) also highlighted that a person of dominant culture tends to disguise recognition of his or her own culture (ethnicity) due to the fact that polarisation no longer exists as he or she tends to overvalue his or her racial and ethnicity appreciation. More to the point, Bennet (2013) believed that a dominant-culture minimiser may be relatively tolerant, but the minimiser, however, fails to appreciate other cultures because of his or her inability to see his or her own culture clearly. 
Adding to Bennet's view earlier, a non-dominant culture minimiser's worldview, on the other hand, involves the acceptance of the same universal standard which can be applied to both dominant and non-dominant cultures of the minimisers' without bias, in which all standards are not constrained by cultural contexts. Although Hammer et. al (2003) positioned minimisation towards the end continuum of ethnocentric experience and towards the beginning continuum of ethnorelative experience, Bennet (2013) insisted that the experience of minimisation is still theoretically ethnocentric because explanations of others' similarities are made using one's cultural belief even though non-stereotypical ways of perceiving some cultural differences and recognisation of essential humanness abilities are included in the experience.

\section{Discussion}

Anthony's "A Certain Cry" is a story of two men hunting for frogs which focus on the traditional rural teachers' life during pre-independence Malaya. This story revolves around four characters, namely Mick, a good frog hunter who is heartless and impatient; Jiga, a merciful and selfless teacher; Mick's father, a man who believes in rituals; and the author/narrator himself, a teacher who claims himself as a good cook. The story ends with the captured frogs being cooked by the narrator while Jiga, at the same time, releases some of the small ones. Throughout the story, Anthony's use of first person singular narrator, as the main character, has enabled us to go deeper into her portrayal of thoughts and emotions as Fernando (1981) proposed earlier; thus, providing us ample opportunity to delve further into the main character's ethnocentric experience. The short story only revolves around four of the aforementioned characters of the same background namely Mick's father, Mick, Jiga and the narrator himself as exemplified in the excerpts below:

Mick's father was all for progress and better ways of doing things, except in matters of what he termed 'our custom'. (Anthony, 2006:

87)

This has given us a clear-cut overview that the highest level of ethnocentrism is experienced by the narrator - denial, whereby no visible cultural differences can be seen with regards to the relations of the characters' ethnicities, portraying the way Anthony brings about the narrator's attitude that are too concerned on issues related to ethnicity and an indication of the narrator's preference to socialise only with his own ethnicity (Zahara Aziz et. al, 2007; Comber, 2011; Ng, 2014). Secondly, the narrator himself has also been too comfortable with the familiar members of his own ethnic community; hence, not noticing much cultural differences around him despite the fact that the narrator himself is a rural school teacher.

Jiga, with whom I share the quarters, kept pace beside me as we squelched along the spongy ground unrecognizable as the dust road that led to the little school where we taught. (Anthony, 2006: 88)

The denial experience is also reflected through the narrator's own thought about another person's belief on slaughtering, to his own belief as seen in the excerpt below: 
For instance, the manner of animal slaughter - that had to follow the ritual of his fathers. "It is all right because it is our way," he cried. That was on the day the man came to slaughter the goat for his daughter's marriage feast. (Anthony, 2006: 87)

The other selected short study also by Anthony, "Nannan", revolves around the struggles of a traumatised Burmese-Portuguese grandmother who endure hardships due to her stepmother's cruelties and abusive husband. In the short story, the denial ethnocentric experiences of the Burmese-Portuguese woman as the main character are evident through the dynamicity of the character herself in which, during the course of the narrative, the main character is portrayed as upholding her own culture in terms of her belief in Christianity as the only which is actual, true and powerful as seen in the excerpt below.

Perhaps her traditional Burmese reserve did not encourage more than the annual Christmas or birthday peck on the cheek. (Anthony, 2006:

4)

Once she puts the statue of St. Christopher head first in water. "St. Christopher," she warns, "if you don't help me, I'll leave you there for another three days." Finally St. Christopher is rescued, placed right side up and an act of Contrition and a few flowers for him on the altar are appropriate atonement a la Nannan. (Anthony, 2006: 5)

\section{Conclusions}

As can be seen, the denial experiences are found reflected through the selected main characters in both "A Certain Cry" and "Nannan" using Milton's (2013) Developmental Model of Intercultural Sensitivity, which support earlier views on intercultural sensitivity which indicate that every ethnic group preferred to socialise only with their own ethnicity (Zahara Aziz et. al, 2007; Comber, 2011; Yong, 2013). Our findings also support the view that people with a higher degree of intercultural sensitivity were less ethnocentric than people with a lower degree of intercultural sensitivity (Chen, 2010, p. 6). Additionally, our findings also demonstrate that both narratives are exhibitions of the main characters' denial experiences as they only focus on a homogenous ruralfolk's society and a Burmese-Portuguese suffering experience respectively. As a result, our findings also yield similar results to that of Raihanah's (2009) on Malaysian writings in English which show that ethnic representations have been made essential instead of race consciousness. This then also does not support Zawiah's (2004) proposition that the lack of intercultural sensitivity in Malaysians writing in English was merely due to the language literariness exposed during the writers' schooling years.

Our study on ethnic relations and ethnocentrism in the two selected Malaysian short stories based on (2013) Developmental Model of Intercultural Sensitivity in examining ethnocentric experiences has demonstrated that each type of ethnocentric experience; denial, defense and minimisation of cultural differences, are indeed found embedded in the unconscious minds of the authors through their 
Proceedings of the $1^{\text {st }}$ Annual International Conference on Language and Literature, 18-19 April 2018, Fakultas Sastra, UISU, Medan, Indonesia

portrayals of selected characters. It has provided us an insight on how MLIE has not been able to depict inclusive images of our Malaysian multi-ethnic society and has also shed light on how an intercultural communication lens could be intertwined in the study of literary texts.

\section{References}

Anthony, C. (2006). A Certain Cry in Fernando, L. Malaysian short stories (Ed.), (pp. 8791). Kuala Lumpur: Maya Press Sdn. Bhd.

(2006.). Nannan in Fernando L. Malaysian short stories (Ed.), (pp. 1-7). Kuala Lumpur: Maya Press Sdn. Bhd.

Bennet, M. J. (2013). Basic Concepts of Intercultural Communication: Paradigms, Principles, and Practices (2nd ed.). Boston, United States: Nicholas Brealey Publishing Ltd.

Chen, G. M. (2010). The Impact of Intercultural Sensitivity on Ethnocentrism and Intercultural Communication Apprehension. Intercultural Communication Studies, XXX (1), 2010th ser., 1-10. Retrieved from https://pdfs.semanticscholar.org/c33c/af79a4c6d70eda682bcafd19e6b9461dd 869.pdf.

Comber, L. (2011). Peristiwa 13 Mei sejarah perhubungan Melayu - Cina. Petaling Jaya: IBS Buku Sdn. Bhd.

Fadhillah, A. N. (2013). Gender representation in selected children short stories of K.S. Maniam (Unpublished Master's thesis). International Islamic University of Malaysia, Gombak.

Fernando, L. (1981). Malaysian short stories of the seventies in Quayum, M. (Ed.), Malaysian literature in English: A Critical Reader (2001), (pp. 74-79). Petaling Jaya, Selangor: Pearson Education Malaysia. . (2006). Malaysian short stories. Kuala Lumpur: Maya Press Sdn. Bhd.

Kinder, D. R., \& Kam, C. D. (2009). Us against them ethnocentric foundations of American opinion. Chicago: University of Chicago Press.

Malaysian Examinations Council. (2011b). 2012 Literature in English Syllabus Specifications and Sample Questions. Retrieved from http://portal.mpm.edu.my/documents/10156/28d2cd05-be4c-48a2-b967bd0a14f4d24e

Malaysia Racial Discrimination Report 2016 (pp. 1-37, Rep.). (2017). Kuala Lumpur: Pusat KOMAS. Launched on March 21, 2017 in conjunction with the International Day for the Elimination Racial Discrimination

Malaysian Department of Statistics. (2017, July 14). Anggaran Penduduk Semasa Malaysia, 2016 - 2017 [Press release]. Retrieved from https://www.dosm.gov.my/v1/index.php?r=column/pdfPrev\&id=VUdaQ2tVVjc wTEFUVWp5aTVQbjV1UT09.

Muis, M. A., Mohamed, B. A., Rahman, A. A., Zakaria, Z., Noordin, N., Nordin, J., \& Yaacob, M. A. (2012). Ethnic Plurality and Nation Building Process: A Comparative Analysis between Rukun Negara, Bangsa Malaysia and 1Malaysia Concepts as Nation Building Programs in Malaysia. Asian Social Science, 8(13). doi:10.5539/ass.v8n13p153. 
Mustapha, I. M. (2014). The politics of bangsa Malaysia: Nation-building in a multiethnic society. Sintok: UUM Press.

Quayum, M. (2001). Malaysian literature in English: A critical reader. Petaling Jaya, Selangor: Pearson Education Malaysia. . (2008). Interrogating Malaysian literature in English: Its glories, sorrows and thematic trends, Kunapipi: Journal of Postcolonial Writing, 30, 149-168

Raihanah, M. M. (2009). Malaysia and the author: Face-to-face with the challenges of multiculturalism [Abstract]. IJAPS, 5, 43-63. Retrieved from http://ijaps.usm.my/wpcontent/uploads/2012/06/Raihanah_MalaysiaMulticul turism.pdf.

Rauf, R. A. (2016). Mediating effect of ethnocentrism on relationship between social networking site factors and social solidarity (Unpublished doctoral dissertation). Universiti Putra Malaysia .

Wan Hussin, W. (2011). Nation-building and 1Malaysia concept: Ethnic relations challenges in the educational field. International Journal of Humanities and Social Science, 1(Special), 228-237.

Yong, N. L. (2013, August 5). Hubungan Kaum di Malaysia. Utusan Malaysia Online. Retrieved from http://ww1.utusan.com.my/utusan/Rencana/20130805/re 06 Hubungan-kaum-di-Malaysia.

Yunus, A. (2017, March 22). Report: Racial discrimination still significant in Malaysia. New Straits Times. Retrieved from https://www.nst.com.my/news/2017/ 03/223152/report-racial-discrimination-still-significant-malaysia.

Zahara Aziz, Amla Salleh \& Jainabee Kassim. (2007). Perpaduan negara: Satu kajian dalam masyarakat negeri Selangor. In Abdul Razaq Ahmad \& Anuar Ahmad, Pendidikan dan Hubungan Etnik (pp. 154 - 174). Bangi: UKM Press.

Zawiah, Y. (2004). The other side of exile: Malaysian writers who stayed behind. In Hanne, M. (Ed.). Creativity in Exile: Rodopi Perspectives on modern literature (pp. 245-254). 